\title{
Finding identity in a virtual world
}

We are living in a world where we each belong to diverse groups. We identify with these. Yet, most times they fragment our friendships, with even good friends belonging to a few of our circles. This is increasingly true of families, organisations and communities. Some of us find little in our living or work communities relating primarily to scattered people in other geographical settings.

In 1968, I started a paper for Resources for the Future, imagining a room in which there were many tables. ${ }^{1} \mathrm{At}$ each, they were playing a different game. However, pieces from one game appeared on the other boards. Soon each game contained players and rules of the others. Meanwhile, people were banging on the doors. "Let us in! We want to play." "No!" was the response, "You do not know the rules of the game?" "But, your rules are changing!" While, psychedelic lights of all colors were flashing on and off, they heard discordant sounds.

How does one live in this increasingly complex world? Too often it feels as confused as that story. We see the issues in running a city, in deciding what education institutions should be, in redefining the role of the military, designing a library and much more. Our concern in this paper, is not to diagnosis, but rather find ways of getting out of the mess. Just when we are asking who are we, what is our identity, and what is our relationship to the world around us?

When you look at a problem, the easiest solution is to use the skills you know. We, whether individuals or institutions, tend, in fact, to always call on skills that have worked for us before. Most frequently, in this rapidly changing world, they do not work. Thus, the all too frequent, inertia for change.

My old friend Tarzie Vittachi, an Asian journalist, and former Deputy Director of UNICEF, always asked for "the news behind the news." By that he meant it was important to understand the complex, often conflicting issues that lie behind a problem.

For example, to understand high infant mortality rates, going beyond medical understanding is important. The fact that poverty, income, women's education, food, sewage systems and political power play as important a part as medical care. Family planning for dealing with high birth rates is not purely a problem of contraception. These broader issues are deeply involved.

We are, however, using narrow policies to deal with these issues, internationally, nationally and locally. The key consultants and administrators are sure they are right, demeaning any new paradigm. Similarly, they defined one's identity in the old paradigms. In doing, meeting the needs of the new world is more difficult.

Let us look at another issue that is very different. How should one redesign a library to meet coming needs? The answer is often to request a bigger budget, and to buy the books and increasingly expensive journals, create more space. The computer experts come up with a solution of putting everything on line. Looks simple?

Nevertheless, what about the browsers who love to touch books, and to see what is on related shelves? That is not all. The topics used are topics - and with it even specialised libraries-to cover cataloging and location.

We have suggested that boundaries are being broken. Fields are running into fields, to the extent that one has to look at issues systemically in an ever changing environment. What do we do? Rearrange the book? Another problem rears its ugly head. They are cutting the budgets. Where do we cut? We need the books and journals, so we cannot cut there. "Cut the number of skilled, expensive librarians!" Is this wise? Or, do we need librarians who can help in putting together and integrating pieces? Or, should we create tools where computers can assist us? Sadly, the intelligence of computers can only do a partial job.

Amazon.com has an interesting solution for browsers. Their recommendation to a buyer choosing a book, is to point to books that previous buyers were also buying. With reviews by services and individuals you can often point to other books.

Libraries must look at books in a very different way. Where are the resources? Other libraries certainly, and interlibrary loans work. On line journals and book are available, but not covering all the material needed. There are private and personal libraries, which in a university are not usually part of the available resources. Bought under grants, they probably should be. Outside the university and in the community are corporate libraries. Should they be in the new complex system? Of course they must work out copyright questions and payments. We need new legal processes.

I do not want to push the library question except as an illustration of what we mean by education. In universities, libraries are considered service organisations. Is this correct, or are they academic teaching ones?

In education, is the school the prime educator. No, as the military and business have gigantic educational operations. Is televison, education for good or bad? What about the rest of the media? Our friends, peers and colleagues? Do children learn from the streets? What is the role of family? Is the emerging education paradigm that of a virtual lifetime university, education wherever one can, using all the resources available?

Steven Bingler, has been designing schools throughout the United States with intimate connection to the community resources. In Tishomingo County School System, in Mississippi, he created with the community a school whose library, kitchen and theatre serve the community as a whole. He has intentionally made the community the larger school, and involved all its people in the process. In many other situations, he has turned communities, museums and businesses into pieces of true school systems.

How then to get to the meat of the issues? What is education? Is it purely skill oriented? Is it cognitive? Artistic? Physical? Or, the many other ways of learning Howard Gardner suggests. ${ }^{23}$ The answers are value issues and professional educational matters. Thus, politics comes in. How do the political decisions get made?

Is politics purely electoral? Can politicians decide these matters? Often, they ask for help. Those they ask, are the well known, and not necessarily those who are on the cutting edge of ideas. The varied techniques used to survey popular beliefs, often represent the current ideas in good currency. How do we test the limits? Can we afford-, our politicians say "No!-One should not deal with the deviants, and those out on the edge," unless of course, they see profit.

Thus, the definition of profit becomes important. Currently, we face a world where the market dominates, and the so called bottom line, is always money. As a cynic, I have suggested that we use money as a common language, because we have no other way to discourse and work out the major differences in our confusing diverse world. Money is the current lingua franca that determines power, development, education and more. 
With all the diversity there are multiple languages, in our case all talking English. These languages reflect values, priorities and cultural histories. To learn to cross these language boundaries, takes time and effort. We must learn them, the way one has to learn how to use telephones in another country, or understand the rules of social intercourse.

Conflict resolution is one way to work out these issues. Sadly, conflict resolution appears to most as weak. It is giving something away or losing. It is not making community. Compromise means to promise community. To make a family, in the old model is to ask the weak-women or child - to conform to the rules of patriarchy. Our emerging families are more equitable, and are not top down, where control is the key way of management.

The new emerging family deals with non-control, allowing each, to be uniquely themselves, yet having a glue, that makes it a family - the willingness to be with each other over time. It is a choice. The glue is not cognitive, or often not conscious. Rather it is what the 60 s called vibes. It feels right. "I know it's right, because I feel it in my gut!"

Still, pulling together diverse people is not easy. The inertia exists to keep things as they are. One patient, once told me, "It is easier to stay neurotic and in pain, than to try to work on changing myself." He was honest, as for him, he needed to find a new paradigm for himself, in his relationship to family and in work.

I want to briefly focus on the development of family therapy, because many of the models of systems intervention, were developed there. Family therapy is a field that developed because often the patient was part of a larger systems problem. The patient is often the "ostensible patient," and the real issue being the faulty family dynamics. Classic therapists for a long time rejected family therapists, as not being kosher. Yet now, ever more are forced to move from the narrower perspective to the whole. Doing so, permits one to deal with, both the problem and the context. What results is a new organism, the system, which must be dealt with. ${ }^{4}$

Many people have contributed to working on such issues. Rather than reviewing them, it is worth stating that we see this going on in, among many others, family therapy, work with institutions, businesses, the military and communities. Slowly, ideas and transfer of metaphors are occurring from one field to another. ${ }^{5}$

One of my favourite examples comes from Defense Department in the Kennedy Administration. MacNamara collected a group of Whiz Kids, who helped create Program Planning and Budgeting System (PPBS). When the Viet Nam war ended, there was concern about switching the military-industrial complex to domestic issues. In one case they transferred PPBS to the Department of Health Education and Welfare, and we began what ended in managed financial care in medicine. One of the Whiz Kids, Alain Enthoven, even became the guru of managed care, giving it its monetary base. We are now living with the unintended consequences of our desires to demilitarise. That is what happens so often with transferring ideas from one field to another, without asking the deeper questions.

That the military is the problem is wrong. For they too, are asking what the new military is. They have told me that some say those aircraft carriers, planes and massive troop concentrations are obsolete. What is the new military is mobile small forces, information systems, and missiles. While I am not involved in this area, I respect those who are asking questions of their own institutions, whatever they be.

For the past 15 years, a worldwide programme of Healthy Cities has emerged. Although, facing some most difficult situations of governance, cities and communities are struggling to find new answers. Sadly, in the old power structure, the top of the hierarchical pyramid of power is usually the national government. Increasingly, we are finding that they are out of touch with communities. For these communities are experimenting with new patterns of governance, dealing with diversity and more.

As a response to the inadequacy of dealing with health care, the move to the larger concerns of communities has developed worldwide. Simply put 7500 cities and communities, are working on so called small problems, leaving the big ones to national governments. The small ones are primarily, those of daily life, food, health, housing, water, sewage, recreation, jobs and active participation in dealing with what effects their lives. Here the issue is creating policy from the ground up. ${ }^{6}$

Learning to cope, finding out what resources are available locally, and learning to use them are their tasks. Learning takes time. Yet, we have already seen changes. To the cynical, the changes are often not measurable. They are changes in process, involvement of people, focus on new issues, and reallocating resources.

It specifically interests me that health is both in the vanguard of change in Healthy Cities, and in the most rigid of market models, in managed financial care. The latter was to solve our problems. What it lacked was understanding the context of medical care, and by selling out health, as a right to one requiring that people earn the chance to get health care.

In each community-and some are really old wines in new bottles-the new pattern of governing diversity is present. This is not a health programme alone. It is one dealing with the broader restructuring of society and of politics and governance.

There are many challenges ahead. I believe we are up to it. What isn't, are the old institutions, and political structures we have used to run our lives. It is time for a change.

LEONARD DUHL

410 Warren Hall 7360, University of California, Berkeley, $C A$, 94720-7360, USA

1 Wingo Jr L. The human measure man and family in megalopolis. Cities and space. The future use of urban land. Baltimore: The Johns Hopkins Press, space. The future

2 Gardner H, Kornhaber ML, et al. Intelligence multiple perspectives. Fort Worth, TX: Harcourt Brace College Publishers, 1996:xiii, 351

3 Gardner H. The disciplined mind: what all students should understand. New York: Simon and Schuster, 1999.

4 Duhl L. Confessions of a psychotherapist. Topeka: Menninger Clinic Bulletin. (In press).

5 Schoen DA. Displacement of concepts. London: Tavistock Publications, 1963: 208.

6 See www.healthycities.org on the internet for an overview of what is going on worldwide. 